(RESEARCH ARTICLE)

\title{
Hematological parameters of children with bee sting envenomation in Yola Northeastern Nigeria
}

\author{
Emmanuel Asuquo Etim ${ }^{1,}{ }^{*}$, Adjekuko Ohwonigho Collins ${ }^{2}$ and Jacob Nwonoba Nweke ${ }^{3}$ \\ ${ }^{1}$ Department of Hematology, Federal Medical Centre Yola, Adamawa State, Nigeria. \\ 2 Department of Medical Laboratory Services, General Hospital Asaba, Delta State, Nigeria. \\ 3 Department of Hematology, Faculty of clinical sciences, Ambrose Alli University, Ekpoma, Edo state.
}

Publication history: Received on 07 May 2020; revised on 24 September 2020; accepted on 26 September 2020

Article DOI: https://doi.org/10.30574/wjarr.2020.7.3.0146

\begin{abstract}
Bee sting envenomation results in alteration of hematological parameters but in Yola, information regarding effect of bee sting envenomation on hematological parameters of children is not well documented. This study therefore aims to examine the effect of bee sting envenomation on children in Yola. 133 subjects participated in this study, comprising of $64($ female $=21$, male $=43$ ) children with mean age of 48 \pm 3.8 months having bee sting envenomation and 69 (female $=$ 31 , male 38) apparently healthy children without bee stings with mean age of $47 \pm 6.1$ months. Hematological parameters of all subjects were determined using Sysmex XN550 hematology analyzer. Mean red cell count of subject was $4.39 \pm 0.3$ $\mathrm{X} 10^{6} / \mu \mathrm{l}$ while red cell count of control group was $4.31 \pm 0.3 \mathrm{X} 10^{6} / \mu \mathrm{l}$ at $\mathrm{P}<0.05$. Platelet Distribution Width (PDW) of subject group was $8.5 \pm 0.4 \mathrm{fl}$ while PDW of control group was $11.5 \pm 1.2 \mathrm{fl}$. Moreover, Mean Platelet Volume (MPV) of subject and control group was 9.2 $\pm 0.6 \mathrm{fl}$ and $9.4 \pm 1.4 \mathrm{fl}$ respectively while subjects had Platelet Large Cell Ratio (P-LCR) of $17.9 \pm 1.0 \%$ while the control group had P-LCR of $23.4 \pm 2.1 \%$. Furthermore, mean total white cell count of subjects and control group were $28.9 \pm 1.4 \times 10^{3} / \mu \mathrm{l}$ and $8.9 \pm 1.6 \times 10^{3} / \mu \mathrm{l}$ respectively and neutrophil counts of children with bee sting envenomation was $23.9 \pm 2.7 \times 10^{3} / \mu$ l while neutrophil count of control group was $3.5 \pm 2.9 \times 10^{3} / \mu$ l. Neutrophil count and total white cell count showed a significant value increase while P-LCR and MPV had a lower value in subject when compare to the control group in this locality.
\end{abstract}

Keywords: Hematological Parameters; Bee Envenomation

\section{Introduction}

Bees are classified into the family of Apidae which comprises of African species Apis mellifera scutellata and European species Apis mellifera linguistica [1] and venoms from bees contain compounds that have applications in medicine and biochemistry [2]. Bee venom is a complex mixture of proteins like melittin and enzymes such as phospholipase, arylamidase, hyaluronidase, $\alpha$-D-glucosidase, $\alpha$-galactosidase, $\alpha$-acetylamino-deosiglusidase [3]. Protein in bee venom have been reported to cause local inflammatory and anti-coagulant activities [4] and certain components of bee venom such as phospholipase $\mathrm{A}_{2}$ and melitin have been reported to be responsible for respiratory paralysis, hemolysis and subsequent reduction in hemoglobin level during bee envenomation [5].

Although deaths due to bee stings are rare and the effect of bee envenomation are dose dependent, most human deaths resulting from one or multiple bee stings have been reported to be due to allergic reactions, heart failure or suffocation from swelling around the neck and mouth [6]. Generally, venoms from most stinging insects like bees induces immediate pain, contains phospholipases, hyaluronidase and are capable of destroying red blood cells [7].

\footnotetext{
${ }^{*}$ Corresponding author: Emmanuel Asuquo Etim

Department of Hematology, Federal Medical Centre Yola, Adamawa State, Nigeria. 
From the hematological stand point, bee venom has been reported to induce peripheral blood leukocytosis [8], and bee venom causes alterations in hematological parameters of rat [9]. In addition, bee envenomation which is a stinging process in which bees introduces its venom into it victim results in intravenous hemolysis, rhabdomyolysis, thrombocytopenia, acute kidney injury and myocardial infarction [5], pulmonary hemorrhage [10], 0ptic neuropathy [11], nephrotic syndrome [12]. The hematological parameters consider for study in this research are: (a) red cell and red cell indices, (b) Platelet and platelet indices (c) Total and differential white cell count.

Surprisingly, in Yola like most part of Nigeria, information regarding the effect of bee sting envenomation on hematological parameters of children is not well documented and this was the impetus for this research. This study therefore aims to investigate the effect of bee sting envenomation on children in Yola so as to elucidate the hematological parameter alterations induce by bee sting envenomation in children. It is believed that information provided in this study will improve the hematologic clinical care of children with bee sting in this locality.

\subsection{Inclusion criteria}

Children with bee stings who did not had folkloric medical care before coming to the hospital were recruited for this study.

\subsection{Exclusion criteria}

Children with bee stings who had had folkloric medical care and have spent more than 48hours after incidence before coming to the hospital were excluded from this study.

\section{Material and methods}

This prospective and descriptive study was carried out at the hematology department of Federal Medical Center Yola in Adamawa State, Northeastern Nigeria between March 2016 to January 2018. A total of 133 subjects participated in this study comprising of 64 (female $=21$, male $=43$ ) children with mean age of $48 \pm 3.8$ months who came into the hospital with bee stings injuries and 69 (female $=31$, male 38) apparently healthy children without bee stings with mean age of $47 \pm 6.1$ months used as control group. All children with bee stings included in this study were clinically diagnosed and were referred to the laboratory for evaluation before commencement of therapy. Other information was retrieved from patient's medical record while the control subjects were recruited from the hospital environment. Hematological parameters of all subjects were determined using Sysmex XN 550 hematology analyzer. All analyses were performed according to the standard operational procedures.

Table 1 Age and sex distribution of children with bee sting envenomation.

\begin{tabular}{|l|l|l|}
\hline Age (Months) & $\mathbf{4 8} \pm \mathbf{3 . 8}$ & \\
\hline & Number & Percentage \\
& Observed & \\
Female: & 21 & $13.4(\%)$ \\
Male: & 43 & $27.5(\%)$ \\
\hline
\end{tabular}

Table 2 Age and sex distribution of children without bee sting envenomation

\begin{tabular}{|l|l|l|}
\hline Age (months) & $\mathbf{4 7 \pm 6 . 1}$ & \\
\hline & Number & Percentage \\
& Observed & \\
Female: & 31 & $21.4(\%)$ \\
Male: & 38 & $26.2(\%)$ \\
\hline
\end{tabular}

\subsection{Sample collection}

$2 \mathrm{ml}$ of blood were drawn from convenient peripheral vein of participant into pediatric K3-EDTA vacutainer tubes. The vacuum tubes were further labeled with child's number, sex, weight and age. Hematological parameters of subject were determined within 3hours of blood collection. All analyses were performed according to the standard operational procedures. 


\subsection{Statistical Analysis}

Statistical analysis was performed using SPSS computer software version 20.0 (IBM Chicago, IL, USA). Descriptive values were given as mean and standard error of mean. Categorical variables were expressed as the number of cases and the percentage value. The Student's $t$-test was used to compare the means differences of the estimated parameters and all statistics were carried out at the probability level of 0.05 .

\subsection{Sample analysis}

Using Sysmex XN550 hematology analyzer, the procedure for hematological parameters determination was performed as follows: EDTA samples were placed in a blood mixer for three minutes and the blood cells were automatically counted through a probe fitted in the sysmex machine. After one minute, the result of the blood cell count was displayed on the colored LCD screen of the machine.

\section{Results}

Sex distribution of subjects reveals that $13.4 \%$ of children with bee sting envenomation were female and $27.5 \%$ were male while $26.2 \%$ and $21.4 \%$ of the control group were male and female respectively as shown in table 1 and table 2 .

Analysis of red cell indices shows that mean red cell count of subject was $4.39 \pm 0.3 \mathrm{X} 10^{6} / \mu \mathrm{l}$ while red cell count of control group was $4.31 \pm 0.3 \times 10^{6} / \mu \mathrm{l}$ at $\mathrm{P}<0.05$. In addition, red cell distribution width-coefficient of variation (RDW-CV) of children with bee sting envenomation was $13.6 \pm 0.7 \%$ while the RDW-CV of control was $13.2 \pm 0.9 \%$. Hemoglobin (HGB) level of subject and control was $12.7 \pm 0.6 \mathrm{~g} / \mathrm{dl}$ and $12.3 \pm 1.2 \mathrm{~g} / \mathrm{dl}$ respectively. Furthermore, mean hematocrit (HCT) level of subjects was $35.0 \pm 1.1 \%$ while HCT of control group was at $39.1 \pm 0.3 \%$. On the other hand, Mean Cell Volume (MCV) of subject was $79.7 \pm 0.8 \mathrm{fl}$ while that of the control group was $75.3 \pm 1$.0fl. Furthermore, Mean Cell Hemoglobin (MCH) of control and subject groups were $25.8 \pm 0.5 \mathrm{pg}$ and $28.9 \pm 0.6 \mathrm{pg}$ respectively. The value of Mean Cell Hemoglobin Concentration (MCHC) of children with bee siting envenomation was $36.3 \pm 0.2 \mathrm{~g} / \mathrm{dl}$ while MCHC of control group was $33.9 \pm 0.4 \mathrm{~g} / \mathrm{dl}$ at $\mathrm{P}<0.05$ as shown in table 3 .

Examination of Platelet and platelet indices reveals that mean platelet count of subject and control groups was $391 \pm 12$ $\mathrm{X} 10^{3} / \mu \mathrm{l}$ and $317 \pm 19.37 \mathrm{X} 10^{3} / \mu \mathrm{l}$ respectively and Platelet Distribution Width (PDW) of subject group was 8.5 $\pm 0.4 \mathrm{fl}$ while PDW of control group was $11.5 \pm 1.2 \mathrm{fl}$. Moreover, Mean Platelet Volume (MPV) of subject and control group was $9.2 \pm 0.6 \mathrm{fl}$ and $9.4 \pm 1.4 \mathrm{fl}$ respectively. Children with bee sting envenomation had Platelet Large Cell Ratio (P-LCR) of $17.9 \pm 1.0 \%$ while the control group had P-LCR of $23.4 \pm 2.1 \%$ as shown in table 4 .

Evaluation of leucocyte count indicates that, mean total white cell count (tWBC) of subjects and control group were $28.9 \pm 1.4 \mathrm{X} 10^{3} / \mu \mathrm{l}$ and $8.9 \pm 1.6 \mathrm{X} 10^{3} / \mu \mathrm{l}$ respectively and neutrophil (Neut) counts of children with bee sting envenomation was $23.9 \pm 2.7 \times 10^{3} / \mu \mathrm{l}$ while neutrophil count of control was $3.5 \pm 2.9 \times 10^{3} / \mu$. Analysis of lymphocyte (Lymph) count shows that subject had a mean absolute lymphocyte count of $3.2 \pm 0.9 \times 10^{3} / \mu \mathrm{l}$ and the control group had a lymphocyte count of $4.1 \pm 2.7 \times 10^{3} / \mu$ l. Furthermore, monocyte (Mono) count of subject and control group was $0.8 \pm 0.3$ $\mathrm{X} 10^{3} / \mu \mathrm{l}$ and $0.6 \pm 0.5 \times 10^{3} / \mu \mathrm{l}$ respectively. Children with bee sting envenomation had eosinophil (Eosin) count of $1.0 \pm 0.1 \mathrm{X} 10^{3} / \mu \mathrm{l}$ while the eosinophil of control group was $0.5 \pm 0.3 \mathrm{X} 10^{3} / \mu \mathrm{l}$ and basophil (Baso) count of subjects and controls were $0.3 \pm 0.01 \times 10^{3} / \mu \mathrm{l}$ and $0.6 \pm 0.2 \times 10^{3} / \mu \mathrm{l}$ respectively as shown in table 5 .

Table 3 Red Cell and Red Cell Indices of subject and control group

\begin{tabular}{|l|l|l|l|}
\hline S/N & Parameters & Subject's values & Control's values \\
\hline 1 & RBC $(\mathrm{X} 106 / \mu \mathrm{l})$ & $4.39 \pm 0.3$ & $4.31 \pm 0.8$ \\
\hline 2 & Hemoglobin $(\mathrm{g} / \mathrm{dl})$ & $12.7 \pm 0.6$ & $12.3 \pm 1.2$ \\
\hline 3 & HCT $(\%)$ & $35.0 \pm 1.1$ & $39.1 \pm 0.3$ \\
\hline 4 & MCV (fl) & $79.7 \pm 0.8$ & $75.3 \pm 1.0$ \\
\hline 5 & MCH (pg) & $28.9 \pm 0.6$ & $25.8 \pm 0.5$ \\
\hline 6 & MCHC (g/dl) & $36.3 \pm 0.2$ & $33.9 \pm 0.4$ \\
\hline 7 & RDW-CV (\%) & $13.6 \pm 0.7$ & $13.2 \pm 0.9$ \\
\hline
\end{tabular}


Table 4 Platelet count and Platelet Indices of subject and control group

\begin{tabular}{|l|l|l|l|}
\hline S/N & Parameters & Subject's values & Control's values \\
\hline 1 & $\begin{array}{l}\text { Platelet } \\
\text { count }(\mathrm{X} 103 / \mu \mathrm{l})\end{array}$ & $391 \pm 12$ & $317 \pm 19.37$ \\
\hline 2 & PDW (fl) & $8.5 \pm 0.4$ & $11.5 \pm 1.2$ \\
\hline 3 & MPV (fl) & $9.2 \pm 0.6$ & $9.4 \pm 1.4$ \\
\hline 4 & P-LCR (\%) & $17.9 \pm 1.0$ & $23.4 \pm 2.1$ \\
\hline
\end{tabular}

Table 5 Total and Differential Leucocyte count of subject and control group

\begin{tabular}{|l|l|l|l|}
\hline S/N & Parameters & Subject's values & Control's values \\
\hline 1 & tWBC $(\mathrm{X} 103 / \mu \mathrm{l})$ & $28.9 \pm 1.4$ & $8.9 \pm 1.6$ \\
\hline 2 & Neutrophil $(\mathrm{X} 103 / \mu \mathrm{l})$ & $23.9 \pm 2.7$ & $3.5 \pm 2.9$ \\
\hline 3 & Lymphocyte $(\mathrm{X} 103 / \mu \mathrm{l})$ & $3.2 \pm 0.9$ & $4.1 \pm 2.7$ \\
\hline 4 & Monocyte $(\mathrm{X} 103 / \mu \mathrm{l})$ & $0.8 \pm 0.3$ & $0.6 \pm 0.5$ \\
\hline 5 & Eosinophil $(103 / \mu \mathrm{l})$ & $1.0 \pm 0.1$ & $0.5 \pm 0.3$ \\
\hline 6 & Basophil $(\mathrm{X} 103 / \mu \mathrm{l})$ & $0.3 \pm 0.01$ & $0.6 \pm 0.2$ \\
\hline
\end{tabular}

\section{Discussion}

Hematological parameters of children with bee sting envenomation in Yola have been analyzed, Sex distribution of subjects reveals that $13.4 \%$ of children with bee sting envenomation were female while $27.5 \%$ were male indicating the predominance of male' children over girls with bee sting wounds in this locality. Table 3 shows red cell count and red cell indices of both subject and control group and in this study there was no significant difference in red cell indices of subject and control group, this result implies that bee venoms had no observable effect on red cell indices of children in this locality. Nevertheless, the platelet distribution width (PDW) of children with bee sting envenomation was lower than that of the control group as shown in table 4 and the reason for this lower value of PDW remains unclear but it is believed that, since PDW is a measure of platelet volume heterogeneity [13]. It goes to show that lower PDW value may reflect decrease heterogeneity in platelet volume and size in children with bee envenomation. Furthermore, P-LCR of children with bee envenomation was lower than that of the control group and Platelet Large Cell Ratio (P-LCR) is a good aid in differential diagnosis of conditions associated with abnormal platelet counts[14][15] which is related to size of platelet. Furthermore, from the platelet indices value, platelet activation is less likely to occur during bee sting envenomation since there was no significant change in MPV which is an indices of platelet activation.

The total white blood cell count (tWBC) of children was $28.9 \pm 1.4 \mathrm{X} 103 / \mu \mathrm{l}$ while the tWBC of the control group was $8.9 \pm 1.6 \mathrm{X103} / \mu \mathrm{l}$ indicating leukocytosis in subject when compare to the control group and strong increase in neutrophil count in subject in this study is believe to be responsible for leukocytosis because large percentage of leucocyte in the peripheral blood is neutrophil [16]. This strong increase in neutrophil count may be due to inflammatory processes [17] in victim induce by bee envenomation since bee sting incidence have been known to be characterized by localized inflammatory processes [4].

\section{Conclusion}

Of the thirteen hematological parameters evaluated in this study, neutrophil count and by extension total white cell count showed a significant value increase in children with bee sting envenomation while P-LCR and MPV had a lower value in subject when compare to the control group. It is believed that information provided in this study will elucidate hematological parameters alteration in children with bee sting envenomation in this locality. 


\section{Compliance with ethical standards}

\section{Acknowledgments}

The authors are sincerely grateful to the management of Federal Medical Center Yola, for providing the environment and equipment for this research work.

\section{Disclosure of conflict of interest}

There is no conflict of interest regarding this work between Emmanuel Asuquo Etim, Adjekuko Ohwonigho Collins and Jacob Nwonoba Nweke who are the co-authors in this research.

\section{Statement of informed consent}

Informed consent was obtained from all individual participants included in the study.

\section{References}

[1] Mingomataj EC, Bakiri AH, Ibranji A, Sturm GJ. Unusual reactions to hymenoptera stings: what should we keep in mind. Clin Rev Allergy Immunol. 2014; 47: 91-9.

[2] Moreno M, Giralt E. Three valuable peptides from bee and wasp venoms for therapeutic and biotechnological use: melittin, apamin and mastoparan. Toxins. 2015; 7(4): 1126-1150.

[3] Son DJ, Lee JW, Lee YH, Song HS, Lee CK, Hong JT. Therapeutic application of anti-arthritis, pain-releasing and anti-cancer effects of bee venom and its constituent compounds. Pharmacol Ther. 2007; 115(2): 246-270.

[4] Hossein Zolfagharian, Mohammed Mohajeri, Mahdi Babaie. Honey Bee Venom (Apis mellifera) Contains AntiCoagulation Factors and Increase the Blood-clotting Time. Journal of pharmacopuncture. 2015; 18(4): 007-011.

[5] Geraldo Bezerra da Silva, Adolfo Gomes Vasconcelos, Joao de Barros Neto, Nathalia Barros Ferreira. Acute Kidney injury complicating bee stings - a review. Rev. Inst. Med. Trop. 2017; 59(1): 289-292.

[6] Abdu Al-Samie MA. Studies on bee venom and its medical uses. IJOART. 2012; 1(2): 1-15.

[7] Schmidt JO, Blum MS, Overal WL. Comparative enzymology of venoms from stinging hymenoptera. Toxicon. 1986; 24(9): 907-921.

[8] Hasan A, Jassim H. Effect of treating lactating rats with lead acetate and its interaction with vitamin E or C on neurobehavior, development and some biochemical parameters in their pups. Ir. J.Vet. Sci. 2011; 1: 45-52.

[9] Zainab I Mohammed, Ahmed J Hassan. Effect of bee venom on some blood and biochemical parameters in formaldehyde induced arthritis male rats in comparison with prednisolone drug. J. Phys: Conf. Ser. 2091; 1234. 012066.

[10] Mukhopadhyay A, Fong KY, Lim TK. Diffuse alveolar haemorrhage: a rare reaction to insect sting. Respirology. 2002; 7: 157-9.

[11] Maltzman JS, Lee AG, Miller NR. Optic neuropathy occurring after bee and wasp sting. Ophthalmology. 2000; 107: 193-5.

[12] Ceri M, Kurultak I. Relapse of nephrotic syndrome after a bee sting. Indian J Nephrol. 2012; 22: 151-152.

[13] Ming-ming, Cui Na, Li Xing, Liu Zhi-yuan, Yun Ye Niu, Young Zhang Boning, Gao Tiemin Liu, Rui-tao Wang. Platelet distribution width correlates with prognosis of non-small cell lung cancer. Sci Rep. 2017; 7: 3456.

[14] Babu E, Basu D. Platelet Large cell ratio in the differential diagnosis of abnormal platelet counts. Indian J Pathol microbial. 2004; 47(2): 202-205.

[15] Buttarello M, Plebani M. Automated blood cell counts: state of the art. Am J Clin Pathol. 2008; 130: 104-16.

[16] Hollowell JG, Van Assendelft OW, Gunter EW. Hematological and iron-related analytes-reference data for persons aged 1 year and over: United States, 1988-1994. Vital Health Stat. 2005; 11: 1.

[17] Turkmen K, Guney I, Yerlikaya FH, Tonbul HZ. The relationship between neutrophil-to-lymphocyte ratio and inflammation in end stage renal disease patients. J. Renal Fail. 2012; 34: 155-159. 